Meta

Journal des traducteurs

Translators' Journal

\title{
Terminological Difficulties in Dene Language Interpretation and Translation
}

\section{Betty Harnum}

Volume 38, numéro 1, mars 1993

La traduction et l'interprétation dans le nord du Canada

Translation and Interpretation in Northen Canada

URI : https://id.erudit.org/iderudit/003026ar

DOI : https://doi.org/10.7202/003026ar

Aller au sommaire du numéro

Éditeur(s)

Les Presses de l'Université de Montréal

ISSN

0026-0452 (imprimé)

1492-1421 (numérique)

Découvrir la revue

Citer cet article

Harnum, B. (1993). Terminological Difficulties in Dene Language Interpretation and Translation. Meta, 38(1), 104-106. https://doi.org/10.7202/003026ar
Résumé de l'article

On rend compte des nombreuses difficultés des interprètes et des traducteurs dénés, qui ont rarement l'occasion de se spécialiser dans un domaine particulier et doivent donc essayer de toucher à un plus grand nombre de sujets possible. On expose les problèmes liés à la création terminologique dans les langues dénés, et on montre comment, à l'aide des méthodes traditionnelles, on peut créer des termes nouveaux. 


\title{
TERMINOLOGICAL DIFFICULTIES IN DENE LANGUAGE INTERPRETATION AND TRANSLATION
}

\author{
BETTY HARNUM \\ G.N.W.T. Department of Justice, \\ Yellowknife, Northwest Territories, Canada
}

\begin{abstract}
Résumé
On rend compte des nombreuses difficultés des interprètes et des traducteurs dénés, qui ont rarement l'occasion de se spécialiser dans un domaine particulier et doivent donc essayer de toucher à un plus grand nombre de sujets possible. On expose les problèmes liés à la création terminologique dans les langues dénés, et on montre comment, à l'aide des méthodes traditionnelles, on peut créer des termes nouveaux.
\end{abstract}

\begin{abstract}
In the Northwest Territories, there are daily demands for interpreting and translating in all the Dene languages. The people who perform this role rarely have the opportunity to specialize in any specific field, so they must try to develop an understanding of as many sub jects as they can. This paper highlights some of the inter-lingual difficulties faced by the interpreters, along with a brief explanation of the methods used to develop new terminology in the Dene languages. It is demonstrated that the methods used in Dene language terminology development are the same as those used in other languages.
\end{abstract}

Since 1984, all of the native languages in the Northwest Territories have been "official", along with English and French, and the Government of the NWT is committed to providing services in these languages to the public. Because of this, interpreters and translators who work in the north are meeting growing challenges in trying to communicate with the non-Dene population. In many ways, communication between speakers of the Dene languages themselves has become more difficult too, as the I/T's strive to find and agree upon suitable equivalents in their languages for the many new concepts, ideas and material items being encountered.

The Dene languages in the Northwest Territories are part of the Athapaskan language family. Based on the 1986 Census of Canada, there are 5350 people in the NWT whose "mother tongue" is a Dene language, while approximately 4320 of these people use their Dene language as a "home language". There are, further, about 985 individuals who speak only a Dene language. Within this language group, which includes Chipewyan, Dogrib, North Slavey, South Slavey and Gwich'in, there is some mutual intelligibility, although Gwich'in is by far the most difficult for speakers of the other languages to understand.

Within each language, there is also a number of dialects, (the number of which depends on the criteria used to define "dialect"), which increases the difficulties in understanding between speakers even of the same language. The differences between these dialects and languages comprise differences in the sound systems, the word-building processes, the sentence structures and other grammatical features, and, most importantly for this discussion, differences in vocabulary, or lexical items. 
Many of the new words and phrases in these languages are the result of independent efforts on the part of individual speakers of the Dene languages to discuss topics from Euro-Canadian cultures for which vocabulary is not readily available in the Dene languages - science, art, technology, law, medicine, land management. That is not to say that this knowledge was non-existent in these cultures prior to contact, but simply that the information is encoded in the Dene languages in a different way. Sometimes, even when I/Ts work together for long periods of time, they have a difficult time agreeing on the appropriate translation of certain terms, since no parallel can easily be identified in languages originating from such diverse backgrounds. However, despite these dilemmas, a great deal of vocabulary is created daily in the process of interpretation and translation, and efforts towards standardization are encouraging the orderly development of this terminology.

In examining data from these languages, it becomes apparent that the methods used to create nomenclature for new lexical items are the same as those which have been identified for other languages. These methods include (but may not be limited to) the following:

a) borrowing a word from the source language, with various phonological changes (sound-changes) in order to adapt the pronunciation of the word to the available sound inventory of the target language;

b) creating a new lexical item by describing some feature(s) of the item, idea or concept; and

c) expanding or shifting the meaning of an existing word or phrase.

Within each of these categories, there are several sub-categories, and some new lexical items combine two or more of these methods. The following discussion will illustrate the methods used.

The items most easy to identify are borrowings. Direct borrowings can be very transparent, such as bebia < "baby", or somewhat less transparent, such as the many borrowings from French, lidi < "le thé" (tea), lifari < "la farine" (flour), lada < "la table" (table). In these French borrowings, the definite article has been incorporated into the Dene noun, and, in fact, many French borrowings in the Dene languages can be identified by this initial ' 1 ', which is not a characteristic of the pre-contact vocabulary. Another type of borrowing is called a "loan blend", in which a word is borrowed and combined with a morpheme that is native to the target language. The word butene < "bouteille" (bottle) makes use of the first syllable of the French word, but adapts the second two syllables to the Slavey word tene "container, bucket,...". In this case, the definite article is not borrowed, while the borrowing has been adapted not only phonologically, but semantically as well, since the word tene already indicates the container-like feature of the bottle.

The creation of new lexical items involves putting together morphemes to create a word, or words to create a phrase, that describes some specific feature(s) of the referent. Sometimes these new words or phrases become lexicalized, that is, they take on a meaning that is more than the sum of the parts, and must be listed in a dictionary as separate items. The various translations of the word for "airplane" exemplify the difficulties that interpreters and translators sometimes face in trying to decipher what another speaker of the same language, or even of the same dialect, means by the word or phrase in question. One translation, "big bird", makes reference to the characteristics that are common between planes and birds, while another translation "paper carrier", makes reference to the function the plane has, that of bringing the mail.

Still another translation for "airplane" makes use of the third method, expanding the meaning of an existing word, as well as of the second process, describing some feature of 
the item. The translation is elá k'enet'ah "boat that flies", which expands the meaning of the word "boat", but also describes the unusual characteristic (for a boat) of flying.

These terminological variations exist throughout the lexicon and create added problems for interpreters who are trying to interpret from their Dene language into English. Aside from these problems, there are differences between the cultures and between the Dene languages and English, (described elsewhere), that complicate the transfer process. It makes the challenge more frustrating and more enjoyable at the same time, and is just one more reason why interpreters and translators should be allowed to participate in training and terminology development sessions at every opportunity. 